\title{
A Microgênese da Explicação de um Problema Ambiental: Os casos Paulo e Piter
}

\author{
Marcelo Eichler ${ }^{12}$ \\ Universidade Federal do Rio Grande do Sul \\ Léa da Cruz Fagundes \\ Universidade Federal do Rio Grande do Sul
}

\begin{abstract}
Resumo
Nesta pesquisa, os objetivos foram os de descrever e interpretar a reconstrução cognitiva que alguns sujeitos exemplares fazem do nexo causal de um problema ambiental. O estudo de caso foi realizado com a colaboração de oito participantes, com idades entre 14 e 17 anos de idade. A tarefa apresentada aos sujeitos consistia na proposição de um problema simbólico, simulado em computador, a ser solucionado durante sessões. Os dados foram obtidos através de observação sistemática, de entrevistas clínicas e de arquivos de histórico. Para este artigo, foram examinados os protocolos de dois sujeitos considerados prototípicos. O estudo das condutas cognitivas relacionadas à análise ambiental permitiu corroborar um modelo, de inspiração piagetiana, para a microgênese dos conhecimentos.

Palavras-chave: Microgênese cognitiva; simulação e solução de problemas; análise ambiental.
\end{abstract}

The Microgenesis of an Environmental Problem Explanation: Paulo and Piter Cases

\begin{abstract}
The aims of this research were to evince the cognitive reconstruction of the causal nexus of an atmospheric pollution case. The research was carried out with the contribution of eight participants whose age varied from 14 to 17 years old. The task given to the participants consisted in the solving of a symbolic problem which was simulated in the computer, and which was supposed to be solved within sessions. Data were obtained through systematic observation, clinical inquiry and log files. For the aim of this paper, two subjects considered prototypes were examined, one of them due to his ease and quickness in problem solving and the other one because of his difficulty and lateness. The development of the environmental analysis progress is discussed.

Keywords: Cognitive micro genesis; simulation and problem solve; environmental analysis.
\end{abstract}

A instalação de um complexo fabril, a ampliação de áreas agropecuárias e a construção de uma estrada têm, pelo menos, uma prática em comum: a necessidade, prevista e regulamentada em lei, de estudos de impacto ambiental (EIA). Esse tipo de estudo se torna importante porque há vezes em que a ação antrópica, ou seja, aquela ação decorrente da atividade humana que produz alterações no meio ambiente natural, alcança situações sem precedentes, onde são impotentes as lições aprendidas anteriormente (Giacoia Jr, 1996).

\footnotetext{
${ }^{1}$ Endereço para correspondência: Área de Educação Química/UFRGS Av. Bento Gonçalves, 9500, Sala D114, Campus do Vale, CEP 91501-970, Porto Alegre, RS. Fone: (51) 3316.6270, Fax: (51) 3316.7304. E-mail: exler@vortex.ufrgs.br

${ }^{2}$ Agradecimentos ao CNPq pelas bolsas de pesquisa concedidas aos autores desta pesquisa; ao coordenador da Área de Educação Química, Prof. Dr. José Cláudio Del Pino, pelo contínuo apoio às discussões interdisciplinares; e ao Colégio de Aplicação da UFRGS pela estrutura que cedida para desenvolver esta pesquisa.
}

Em relação ao exercício profissional, verifica-se a dificuldade do analista em incorporar todos os fatores que podem influir nas descrições, explicações ou predições da análise do impacto ambiental (Fowler \& Aguiar, 1995). Algumas dessas dificuldades são: (1) relacionar todos os componentes de um sistema; (2) prever as interações entre problemas menores; (3) não incluir aspectos que seriam considerados irrelevantes ou fora da área de especialidade; (4) não considerar a fragilidade das premissas da teoria de referência, ou não dar atenção suficiente ao problema de amostragem estatística; e, (5) excluir conscientemente aspectos subjetivos, classificando-os como não importantes, visando com isso simplificar a análise. Assim, as disciplinas que simplesmente justapõem um adjetivo "ambiental" à sua prática prévia não contribuem para elucidar os problemas ambientais. Tais disciplinas “(...) apenas acabam recaindo em uma atividade aplicativa que de pouco ou nada adianta para uma explicação compreensiva (...) da complexa questão ambiental." (Rohde, 1996, p. 82) 
Porém, as condutas cognitivas e os valores nem sempre, ou raramente, estão racionalizados. Nas questões ambientais, na maioria das vezes, não se sabe o porquê de uma ou de outra conduta. Faz-se porque é bom ou porque é melhor. Algumas poucas vezes, os esboços explicativos que os sujeitos apresentam estão relacionados a um dos diferentes sistemas compreensivos relacionados ao ambientalismo (por exemplo, jurídico, econômico, físico-químico e ecológico). Porém, muito pouco se chega a uma efetiva elaboração deles todos. De outra forma, um maior entendimento sobre um ou outro desses sistemas compreensivos pode ter implicações que favoreçam a emergência dos valores que estariam relacionados a uma ética ambiental ou ecológica (Dias, 1992).

Nesse sentido, do ponto de vista psicológico, pode ser interessante um estudo inicial e exploratório, de perscrutação, sobre a reconstrução cognitiva do vínculo causal na análise ambiental. Para tanto, a polêmica sobre a diminuição da produção agropecuária em localidades próximas a usinas carboelétricas (Eichler \& Del Pino, 2000; Fiedler, Martins e Solari, 1990; Fiedler e Solari, 1991) serviu de tema para esta pesquisa sobre o problema da poluição ambiental.

Dessa forma, parece pertinente inscrever o tema do estudo empreendido em relação a causação. Bunge (1959/ 1997) expõe algumas condições para se desenvolver um estudo da causação, advertindo que tais condições se referem a feitos e não à reconstrução cognitiva que se faça deles - sendo esse último o objetivo desta pesquisa. Por assim dizer, as condições de validade das idéias causais dependem, antes de tudo, da natureza do objeto. Tais condições são postuladas através dos seguintes enunciados: (1) que as principais mudanças em consideração sejam produzidas por fatores externos (por exemplo, o predomínio dos fatores externos sobre os internos se observa, sobretudo, na técnica e na indústria); (2) que o processo em questão possa ser considerado como isolado (é lícito considerar o processo em questão como arrancado de suas interconexões reais; isso é muitas vezes possível durante intervalos limitados de tempo); (3) que as interações possam se aproximar por relações agente-paciente (é típico da produção e da tecnologia humanas considerar a matéria-prima como um paciente sobre o qual se exerce o trabalho humano); e, (4) que o antecedente e o conseqüente estejam vinculados entre si de maneira unívoca (ou seja, cada efeito pode ser considerado como procedente em forma única de uma causa fixa).

No problema de poluição ambiental em estudo, todas essas condições estão contempladas. Para a condição (1), por exemplo, o que muda é a composição da atmosfera, que é realizada por um fator externo provocado por uma indústria de transformação que utiliza uma certa técnica poluidora. Então, é possível usar o princípio causal para explicar o feito observado. Em (2), o processo de poluição é considerado de forma isolada. Considera-se o que está reagindo quimicamente na atmosfera em um contexto hipotético. Esse não compreende a totalidade da realidade da atmosfera, uma vez que não leva em conta uma série de reações químicas que são a ela características, mas totalmente irrelevantes para o problema que se está estudando. A validade do princípio permanece. Em (3), a consideração é fundamentalmente similar à (1). Em parte, essa é uma índole da química que, embora possua manifestações espontâneas, tem seus processos forçados - não naturais, antrópicos - passíveis de serem descritos a partir da relação agente-paciente. Há o equilíbrio, mas esse não tem uma decisiva diferença no feito que se está estudando. Mais uma vez, o princípio causal pode ser usado. Finalmente, em (4) a descrição de nexo causal é suficiente para verificar a validade do princípio. Os efeitos nocivos à saúde dos animais e das plantas, que afetaram a economia da região, foram causados pela formação e precipitação de chuva ácida, cujo caráter é função da qualidade do ar. Essa, por sua vez, foi alterada pela emissão de gases, com uma considerável concentração de dióxido de enxofre, provocada pela queima de carvão com altos índices de enxofre.

Além do mais, esse problema não diz respeito somente à química ambiental. A poluição ambiental é, ou deveria vir a ser, uma questão de todas as áreas do conhecimento que lhe sejam tangentes, entre elas, a educação, a comunicação, a economia, o direito, a biologia, as engenharias e a meteorologia (Tauk-Tornisielo, Gobbi \& Fowler, 1995). Por exemplo, a questão do impacto poluidor dos complexos carboelétricos passa pelas políticas públicas de planejamento e gerenciamento da matriz energética adotada, o que envolve questões relacionadas à economia e ao direito, entre outros. Por isso, entendemos que, com certos problemas ambientais que têm um nítido domínio causal, é possível realizar um estudo para verificar as condutas cognitivas manifestas, as estratégias que os sujeitos desenvolvem em suas análises e os sistemas compreensivos a que se reportam. No entanto, buscar as explicações, os entendimentos, as compreensões dos sujeitos não é uma tarefa que apresenta muitas facilidades. Primeiro, porque o entendimento ocorre na mente do sujeito e esse processo não é aberto a observações diretas ou manipulações (Newton, 1996). Segundo, determinar quão bem um sujeito entende a relação causal que ele atribui aos objetos não é uma matéria fácil (Bindra, Clarke \& Shultz, 1980). Finalmente, 
uma exaustiva análise da literatura sobre os processos conversacionais adverte que em situações de pesquisa os sujeitos podem omitir certos fatores em suas explicações, não porquê eles acreditem que esses fatores não tenham qualquer papel causal em produzir um evento, mas porquê eles consideram esses fatores irrelevantes para a questão que lhes foi perguntada (Hilton, 1990). Dessa forma, compreendemos que métodos qualitativos de inspiração piagetiana podem superar tais dificuldades.

Entendemos a epistemologia genética, formulada por Jean Piaget, como um modelo para a teoria do conhecimento, cujo principal objetivo é o estudo dos mecanismos de mudança do conhecimento no curso da construção de conceitos científicos. Em outras palavras, trata-se de investigar os mecanismos de passagem de um estado de conhecimento menos desenvolvido para um outro mais desenvolvido. Dessa forma, sugere Freitag (1997, p.7) que “(...) a melhor demonstração de admiração e respeito que se possa dar a uma obra substancial é debatê-la a fundo, é confrontá-la com outras obras de peso, em suma: é levá-la a sério."

Nesse confronto, segundo Garcia (1996, p. 57) “(...) é natural (...) que novos dados experimentais ampliem, restrinjam ou modifiquem resultados obtidos pela escola de Genebra no domínio das investigações psicogenéticas.". Principalmente porquê, de acordo com Ferreiro (1996), o legado piagetiano pode ser concebido como uma teoria geral de processos de aquisição de conhecimento, desenvolvida em domínios relacionados ao pensamento lógico, às grandes categorias de espaço, tempo e causalidade, bem como as noções matemáticas e físicas elementares, “(...) mas potencialmente apta para dar conta dos processos de construção de outras noções em outros domínios." (Ferreiro, 1996, p. 177). Mas, conforme adverte Delval (1996), não se deve confundir as atribulações características de um domínio com as formas de construir o conhecimento nos diferentes domínios. Além disso, cabe lembrar que o projeto de pesquisa piagetiano estava relacionado “(...) às partes estabilizadas das ciências e não [as] que ainda se procuram.” (Grize, 1997, p. 73)

Então, na medida que “(...) não existe uma abordagem teórico-conceitual consagrada (...) [para] avaliar quaisquer processos de transformação ambiental." (Macedo, 1995, p.14), pode-se imaginar a dificuldade de realizar estudos de natureza psicogenética. Assim, ao estudar o domínio das ciências ambientais, resolvemos desenvolver uma pesquisa que permitisse sondar, perscrutar, explorar esse domínio para verificar questões que pudessem ser profícuas para próximas investigações. Por isso, a metodologia escolhida para esta pesquisa foi o estudo microgenético (Inhelder \& Cellérier, 1992/1996).

Uma análise microgenética permite um estudo dos esquemas gerais orientados para o entendimento (compreensão, no original), e das estratégias direcionadas para o sucesso na ação, bem como dos processos de invenção ou de descoberta das crianças ou dos adolescentes na solução de problemas particulares (Inhelder \& Caprona, 1992/1996a). Assim, “(...) trata-se de examinar, minuciosamente, o que o sujeito utiliza para ter acesso a possibilidades de que ele não dispunha no princípio ou, em outras palavras, como ele se vale do que sabe fazer para aprender aquilo que ainda não conhece." (Inhelder \& Caprona, 1996b, p. 56)

Essa abordagem, portanto, indicaria as condições sob as quais as mudanças ocorrem e permitiria o exame das seqüências típicas dos processos de desenvolvimento (Branco \& Rocha, 1998). Também, uma das possibilidades de uso dessa abordagem seria o fornecimento de informações críticas para refinar análises teóricas, entre elas o papel dos impasses na descoberta e na generalização (Siegler \& Crowley, 1991). Finalmente, Inhelder e Caprona (1992/1996a, p. 11) entendem que "(...) o pensamento pré-operacional presta-se muito bem às análises de tipo funcional.", mas sugerem que seria interessante retomar os problemas operatórios “(...) sob um ângulo que permitisse o estudo em termos de procedimentos de resolução de problemas.". Portanto, com nossos estudos microgenéticos procuramos levar as análises teóricas de Inhelder e Caprona (1992/1996a, 1992/1996b) para o campo da análise ambiental.

Dessa forma, verifica-se que, em geral, no início da resolução de um problema, o conhecimento inicial ativado pelo sujeito ainda não está atualizado ou especificado (Saada-Robert, 1992/1996a). Esse conhecimento é sincrético, ou seja, é uma reunião artificial de idéias de origens disparatadas, uma vez que a visão de conjunto da totalidade ainda se encontra confusa. Podese entender essa reunião como a amálgama de duas componentes, “(...) [uma] de generalidade difusa relativamente à situação atual, e [outra] de particularismos justapostos em relação aos conhecimentos anteriores sobre os quais se apóia." (Saada-Robert, 1992/1996a, p. 107). Desse entender global e indistinto, surgem os objetos distintamente entendidos, transformando-se progressivamente em um saber ao mesmo tempo preciso e sintético. Portanto, “(...) a construção microgenética consiste (...) numa dupla passagem do difuso ao preciso, e do esparso ao unitário." (Saada-Robert, 1992/1996a, p. 107). Ora, esse sincretismo também ocorre na análise ambiental. $\mathrm{O}$ ambientalismo que integra as idéias iniciais 
sobre ecologia, meio ambiente, proteção, bem como os valores a elas relacionados, deve ser superado e objetivado para que se resolva o problema em foco. Nesse sentido, é justamente essa transformação progressiva que se quis estudar.

Porém, além disso, tivemos que enfrentar duas dificuldades para desenvolver esta pesquisa. Um dos problemas esteve relacionado à possibilidade de serem utilizados, na análise microgenética, os modelos teóricos elaborados por Piaget e seus colaboradores a partir de estudos do desenvolvimento macrogenético. Alguns autores sustentam que os modelos piagetianos (ou suas macrocategorias) não podem ser usados na análise das condutas psicológicas e pragmáticas, que são o objeto da análise microgenética. Por exemplo, a distinção piagetina entre fazer e compreender seria uma questão que envolve a resolução de um problema formal, que exige mais do que o agir sem teoria, que é o que se manifesta em estudos microgenéticos (Mosca, Silveira \& Burigo, 1993). Isso porquê: “(...) o modelo explica as possibilidades do ser humano, não as performances de Jacques ou Jacqueline.” (Ramozzi-Chiarottino, 1997, p. 114; grifo da autora).

A questão parece polêmica e não está de todo resolvida ou consolidada. A própria obra que serviu de referência para nossos estudos microgenéticos (Inhelder \& Cellérier, 1992/1996) contém algumas análises que se valem dessas macrocategorias, assim como possui outras que procuraram desenvolver outras categorias e modelos. Por exemplo, Inhelder e Caprona (1992/1996a, p. 24; grifo nosso) entenderam que “(...) o funcionamento psicológico indica a existência de diversos graus de compreensão, e a interação entre faz̧er e compreender parece atuar constantemente no curso da resolução de problemas.". Esses autores também utilizam as macrocategorias piagetianas para descrever os procedimentos de descobertas e os sistemas de compreensão, citando a tomada de consciência acerca da ação e o papel dos sucessos e dos fracassos manifestos ou inferidos pelo pesquisador, conforme Piaget e colaboradores descreveram em Fazer e Compreender (1974/ 1978) e Tomada de Consciência (1974/1977).

Outro exemplo: Moro (2000, p. 298) desenvolveu um estudo de caso, também segundo as proposições da epistemologia genética, em que utiliza o modelo piagetiano da equilibração para “(...) verificar como ocorre a intricada combinação das dimensões social e individual no processo cognitivo.", ou seja, para explicar a complexidade das interações sociais. Em relação ao objeto do conhecimento, esse estudo procurou verificar as estratégias cognitivas na aprendizagem da adição e da subtração. Na discussão dos resultados do estudo de três casos, a autora verifica o poder explicativo das proposições de Piaget sobre o funcionamento cognitivo regulado pela equilibração, por exemplo: “(...) o papel da tomada de consciência pelo sujeito das ações e dos seus resultados, na conceitualização da ação em novo plano, conforme o movimento da abstração reflexionante." (Moro, 2000, p. 298)

Dessa forma, compartilhamos o entendimento desses autores de que a epistemologia genética oferece construtos explicativos coerentes e poderosos para o funcionamento cognitivo ou, no mínimo, que os modelos e postulados elaborados por Piaget e seus colaboradores podem servir, essencialmente, como quadro de referência para compreender a microgênese das condutas cognitivas. Além do mais, a crítica ao uso de modelos desenvolvidos a partir de pesquisas de interesse epistemológico (como por exemplo, aqueles constantes nos livros de Piaget, anteriormente citados) na descrição de condutas dos sujeitos psicológicos individuais levaria a um paradoxo: não seria possível descrever ou falar das deduções ou induções que realizaram Paulo ou Piter, uma vez que esses processos ou métodos são constructos que fazem parte de qualquer teoria do conhecimento.

Finalmente, o outro problema esteve relacionado à forma de apresentar os resultados desta pesquisa. Embora Inhelder e Caprona (1992/1996b) desenvolvam conclusões acerca de todo o conjunto de suas experiências sob as condutas cognitivas no desenrolar das descobertas infantis (16 tarefas diferentes, nas quais participaram 601 sujeitos entre 3 e 14 anos de idade), não há um consenso sobre a forma de apresentar os dados das diferentes pesquisas. Diversos artigos (Blanchet, 1992/1996; SaadaRobert, 1992/1996a e 1992/1996b) apresentam modelos diferenciados para a descrição e a interpretação dos dados obtidos nas pesquisas sobre a microgênese do conhecimento.

Os resultados das pesquisas de Blanchet (1992/1996, p. 81) são descritos através de “(...) exemplos (...) extraídos da análise de um grupo de 27 crianças de sete a doze anos de idade [que] têm por objetivo ilustrar as definições teóricas apresentadas [anteriormente].”. Esses exemplos são muito similares àqueles utilizados pela tradição de pesquisa piagetiana: consistem de excertos dos protocolos das entrevistas clínicas. No entanto, os excertos de Blanchet possuem uma maior ênfase na descrição das ações e já contemplam uma apreciável quantidade de interpretações das ações descritas. Esses excertos são comentados com uma série de digressões que servem para referendar e reiterar o que já fora dito e constava de início, não como hipótese, mas como afirmação.

Psicologia: Reflexão e Crítica, 2001, 14(3), pp. 505-520 
Além de utilizar os excertos, Saada-Robert (1992/ 1996a) salienta a necessidade de se fazer uma descrição analítica do problema ao analisar as representações que o sujeito faz da tarefa e da solução por ele proposta. Em uma de suas pesquisas, Saada-Robert (1992/1996a, p. 113) relata o desenrolar das ações de alguns dos sujeitos da pesquisa, pois entende que o seu “(...) progresso pode ser considerado o protótipo da microgênese.” da situação estudada. Nesse artigo, Saada-Robert descreve as diferentes partes constantes do processo de resolução da tarefa proposta através de fragmentos das microgêneses de sujeitos diferentes, considerados cada um deles prototípicos na determinada parte a que servem de exemplo. Em outra pesquisa, Saada-Robert (1992/1996b) faz toda a descrição e discussão dos dados através de um único protocolo, considerado, também, um caso prototípico. Assim, a seguinte definição parece importante:

"A análise de um caso prototípico caracteriza-se por um duplo objeto: um 'objeto típico' ou 'objeto exemplar' de demonstração, pois exprime em detalhes e claramente aquilo que os outros sujeitos também resolvem, mas de maneira mais parcial e mais laboriosa ou, ao contrário, de forma mais rápida e mais fácil, é um 'objeto para pensar', fonte de construção teórica. (...) O estudo de caso prototípico, tal como é realizado em um bom número de estudos referentes à representação cognitiva (...), distingue-se do estudo de caso atípico, freqüente em psicologia clínica e em neuropsicologia, e cujo interesse reside precisamente na raridade e particularidade das condutas analisadas" (Saada-Robert, 1992/ 1996b, pp. 129-130; grifos da autora)

Nesse sentido, para atingir os objetivos propostos nesta pesquisa, utilizamos a descrição comentada das evoluções de dois sujeitos prototípicos em relação ao processo de solução da tarefa proposta. Dessa forma, na seção resultados serão apresentados extratos, tanto do protocolo do caso Paulo, escolhido por ter resolvido a tarefa de forma rápida e fácil, quanto do caso Piter, que resolveu o problema de maneira mais laboriosa.

\section{Método}

O estudo de caso, segundo Stake (1994), pode ser entendido como a tipificação de outros casos, seja por uma exploração que leva os estudos a produzirem generalizações ou como um primeiro passo ocasional na construção de uma teoria, de uma noção, de um entendimento. Nesse último sentido, o estudo de caso mais otimiza a compreensão do próprio caso do que a generalização para além dele. Então, o estudo de caso, não só é uma escolha metodológica, mas, também, uma escolha do objeto a ser estudado, qual seja, em nosso foco, a microgênese de conhecimentos.
Sabe-se que pesquisas dessa natureza necessitam tarefas experimentais que contenham manipulação física e um objetivo a ser atingido (Mosca, Silveira \& Burigo, 1993). A manipulação física permite, de certa forma, evidenciar o pensamento do sujeito. O objetivo a ser atingido na tarefa, de maneira complementar, possibilita manifestar a resolução que o sujeito atribui ao problema e a explicação que ele concede a tal. No entanto, essas tarefas, necessariamente, não precisam ser naturais, cotidianas ou reais, ainda mais porque os participantes da pesquisa podem estar muito familiarizados ou muito distantes das questões do estudo (Lawson, 1983), o que tornaria a pesquisa imprópria (White, 1997). Há casos em que são mais propícias tarefas artificiais ou simuladas, desde que elas não sejam nem fisicamente impossíveis, nem muito diferente de alguma atividade real similar (Lawson, 1983; White, 1997). Por exemplo, no domínio da análise ambiental, situações reais chegam a ser muito complexas e demandam diversos conhecimentos especializados, um tempo considerável e um razoável custo para seu término. Assim, alternativas devem ser buscadas para desenvolver pesquisas com os objetivos citados.

Entre as alternativas, talvez, a mais rica é a que utiliza computadores para desenvolver simulações educacionais. Essas simulações possibilitam, entre outras, uma ambientação realista. Nelas, o sujeito é apresentado a um problema simplificado, diante do qual toma uma série de decisões e as executa em direção à solução do problema proposto. Nesse sentido, as simulações permitem que o sujeito verifique o funcionamento de um determinado modelo simplificado da realidade a partir de suas próprias hipóteses (Eivazian, 1995), o que, para o pesquisador, possibilitaria irradiar luz sobre os raciocínios em situações da vida real (Lawson, 1983). Portanto, defende-se que simulações educacionais podem ser usadas para pesquisar as condutas cognitivas relativas à análise ambiental.

Mas, se por um lado, muitos casos interessantes a serem estudados podem ser identificados, por outro, uma menor quantidade desses nos seriam acessíveis, tanto pelas relações conceituais envolvidas na tarefa, quanto pelas instrumentais ou materiais. Dessa forma, em parte, isso justifica a escolha da tarefa que melhor conhecíamos, o software educativo Carbópolis (Eichler, Del Pino, Pesa Filho \& Vianna, 1998). Finalmente, entendemos que, talvez, com uma maior quantidade de estudos, possa-se generalizar sobre as estratégias de resolução de problemas ambientais.

O problema apresentado em Carbópolis consiste na diminuição da produção agropecuária em uma localidade 
próxima a uma usina carboelétrica. Para resolvê-lo, o estudante pode verificar os danos causados, a origem dos mesmos e propor uma solução que venha a diminuílos ou eliminá-los (Eichler \& Del Pino, 2000).

O software foi modelado a partir de dados de uma pesquisa a respeito do potencial poluidor da usina carboelétrica de Candiota, Rio Grande do Sul, Brasil. Essa pesquisa concluiu que as medidas de controle de emissões e as exigências legais eram inadequadas ou insuficientes para evitar a contaminação ambiental (Fiedler, Martins \& Solari, 1990; Fiedler \& Solari, 1991). A situação concreta pode ser assim descrita: na usina de Candiota, a queima de carvão contendo taxas de enxofre maiores que o recomendável, entre 3,5 e 5\% (em Carbópolis essa taxa aumenta para $6 \%$ ), produziu grandes quantidades de dióxido de enxofre, um gás bastante reativo e que é considerado poluente atmosférico. O dióxido de enxofre foi dissipado na atmosfera através da ação dos ventos, em direção ao Uruguai (em Carbópolis, em direção à região agropastoril). A umidade do ar e a água da chuva reagiram com o gás poluente e ocorreu a precipitação de chuva ácida, que queimou os pastos e as lavouras de arroz (em Carbópolis, as lavouras são de soja) e, provavelmente, atacou o sistema respiratório e digestivo dos animais, enfraquecendo-os.

Com o objetivo de levar a termo a resolução do problema na situação simbólica, o software contém: um mapa para auxiliar a situação geográfica do problema apresentado; personagens para descrever o problema; menu e ícones que possibilitam a coleta das amostras de ar e água da chuva sobre o mapa, análise das amostras e instalação de equipamentos antipoluentes; ferramenta de hipertexto com 56 tópicos e mais de 250 ligações ativas; ferramenta de editor de textos para registrar conclusões parciais e o resultado das análises das amostras durante a utilização do software. Também, dois questionários para orientar a conclusão das atividades propostas pelo software (Eichler \& Del Pino, 2000). A Figura 1 representa a principal janela desse programa.

Entretanto, em estudos microgenéticos, há certas necessidades com relação aos dados que são recolhidos para a análise das condutas cognitivas. Nesse sentido, as significações das ações ou das operações só podem ser apontadas pela conjunção das várias indicações manifestas durante a pesquisa, de onde vem a necessidade de um meio de registro que pegue toda a história de cada ação (Mosca, Silveira \& Burigo, 1993). Normalmente, a gravação em vídeo tem sido usada com essa finalidade (Meira, 1994). No entanto, conforme realizado nesta pesquisa, com simulações educacionais podem ser utilizados os arquivos de histórico, que consistem em um

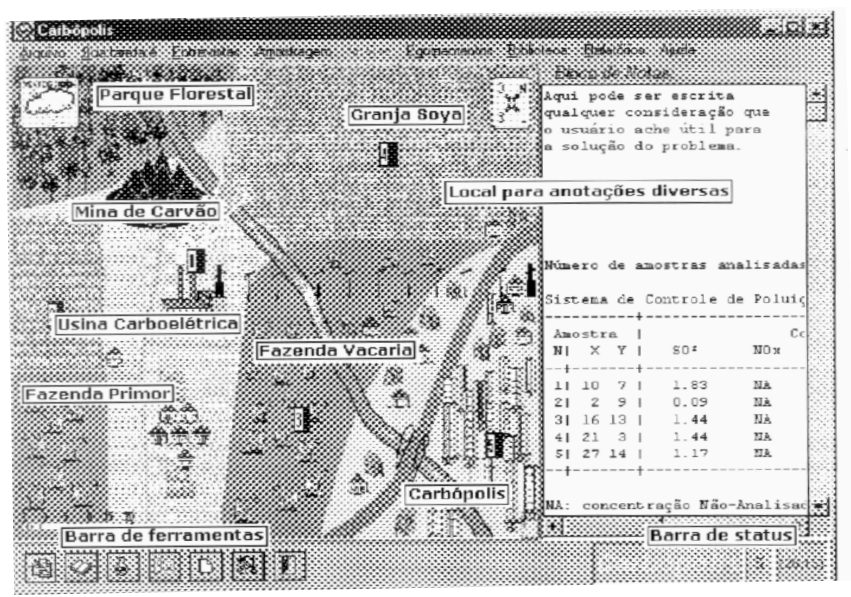

Figura 1. Representação da tela do software Carbópolis

registro de traço e de tempo das escolhas de navegação dos sujeitos quando utilizam um ambiente computacional (Barab, Bowdish \& Lawless, 1997). Esses arquivos são individuais, integrados, contínuos, sem emendas e, normalmente, fazem parte do ambiente da simulação.

O estudo das condutas cognitivas dos aprendizes foi realizado com a colaboração de oito participantes, com idades entre 14 e 17 anos, a partir de um delineamento de estudo de casos (Siegler \& Crowley, 1991). Os participantes utilizaram o software em sessões de 45 minutos, sendo utilizadas tantas sessões quanto fossem necessárias para os participantes resolverem a tarefa proposta. Durante o desenvolvimento da tarefa, foram utilizados a observação sistemática e o método clínico para acompanhar os processos de solução. As interferências do experimentador, que acompanhou todo o processo, foram limitadas. Nesse sentido, as seguintes questões serviram, em geral, como norte para as perguntas que foram efetivamente feitas: 1) quando os participantes conseguissem situar geograficamente o problema, o experimentador perguntaria algo sobre por quê o problema estaria assim situado, como o participante chegara a essa conclusão, qual a explicação que ele poderia dar ao problema e como ele iria resolvê-lo; 2) quando os participantes identificassem uma possível causa ao problema, o experimentador perguntaria por quê o participante atribuíra essa possível causa, como fizera para chegar a tal conclusão, como poderia garantir que fosse essa a causa do problema, qual a explicação para essa possível causa e o quê poderia ser feito para resolver o problema; e 3) finalmente, quando os participantes resolvessem o problema, o experimentador perguntaria como o participante chegara a essa conclusão, como ele poderia explicá-la e se o problema que lhe fora apresentado existe, existiu ou pode existir na realidade. As entrevistas foram gravadas em fitas de áudio e posteriormente transcritas. 
A análise de cada caso foi realizada conforme a tradição de pesquisa de inspiração piagetiana (Inhelder \& Cellérier, 1996). Foram utilizados como dados: a descrição do histórico da utilização do softwvare; os textos escritos pelos participantes durante a utilização do software (bloco de notas e relatórios); e a transcrição das fitas de áudio. A combinação desses três tipos de dados foi efetivada através da construção de protocolos (Stake, 1994). Os dois primeiros tipos de dados permitiram uma descrição do desenrolar das descobertas realizadas pelos participantes, em relação ao problema ambiental. $O$ terceiro se somou aos anteriores para descrever as condutas cognitivas dos participantes na solução da tarefa que lhes fora apresentada.

\section{Resultados}

Devido aos limites de extensão deste texto, serão apresentados pequenos excertos dos protocolos dos dois casos prototípicos analisados com o objetivo de ilustrar a reconstrução cognitiva do nexo causal envolvido na análise ambiental. Nesta pesquisa, provavelmente o caso Piter (15 anos e três meses; resolveu a tarefa em cinco sessões) foi o que permitiu um maior detalhamento e uma descrição mais compatível com a manifestação média na resolução da tarefa apresentada no programa Carbópolis. Os motivos disso foram vários, mas entre eles destacamos: a perda de parte dos dados dos arquivos de histórico (devido à presença de programas de segurança em computadores de uso comum, que impediam a gravação desses dados em diretórios de arquivos de programa); o tempo extenso de utilização do programa; o intervalo entre uma sessão e outra; a utilização do programa sem a assistência do pesquisador, conforme fora combinado; os padrões de navegação dirigidos por noções de economia; a partida de uma indiferenciação inicial e a conclusão em uma integração de conceitos bastante objetiva e completa em relação ao problema proposto. Porém, como algumas dissonâncias são esclarecedoras, quando necessário descreveremos, também, evidências extraídas do caso Paulo (14 anos; resolveu a tarefa em uma sessão).

$\mathrm{Na}$ análise ambiental, conforme abordamos na introdução, a primeira representação que se faz do problema que se está a resolver é função das experiências anteriores dos sujeitos. Algumas dessas representações podem evidenciar uma visão de conjunto confusa, manifestando o ecletismo envolvido na ocasião das primeiras reconstruções de uma totalidade complexa. Assim, escolhe-se as condutas ou opiniões que parecem melhores para a situação em foco, sem que se observe

Psicologia: Reflexão e Crítica, 2001, 14(3), pp. 505-520 uma linha de pensamento mais rigorosa. O caso Paulo é característico a esse respeito.

Paulo, após a leitura do texto inicial, não conhecia o funcionamento e as funções que o programa de computador permite executar. Entretanto, rapidamente diferenciou os ícones e os itens do menu que aparecem na tela (veja a Figura 1) e entendeu a função do botão direito do mouse (que permite verificar os depoimentos de alguns habitantes da região e instalar e desinstalar os amostradores de ar e de água da chuva). Além disso, possivelmente a partir da leitura do texto inicial, Paulo logo diferenciou o significado das figuras do mapa. Por exemplo, rapidamente integrou duas coisas que lhe foram observáveis: as diferentes regiões do mapa e os nomes a elas associadas na barra de status. Dessa forma, a sua entrada na usina já é a segunda ação que desenvolveu com o clicar do mouse. Essa diferenciação inicial foi fruto de um conhecimento prévio sobre efeitos e causas de problemas ambientais gerais, como ele manifestou em entrevista: (Paulo): "Já ouvi falar de vários problemas ambientais, específico assim desse aí, não sel". Assim, mesmo que nesse momento, ele não tenha explicitado um fator causal, provavelmente a imagem da fumaça saindo da usina lhe serviu como indicador de um possível problema ambiental.

Em relação a isso, nada se pôde depreender do caso Piter. Ele não manifestou qualquer ação que permitisse evidenciar algum tipo de conhecimento prévio sobre problemas ambientais. No princípio, também, ele não sabia o que o programa podia fazer e onde ele deveria acionar as funções do programa. O descobrimento do funcionamento do programa foi muito gradual, de tal forma espaçada, que chegou, inclusive, a retardar o descobrimento dos procedimentos a serem seguidos para chegar à solução do problema. A sua sondagem do programa manifestava uma busca voltada ao conhecimento da totalidade e finalidade das funções da ferramenta. Essa tendência perdurou em quase toda a primeira sessão.

Assim, o conhecimento dos procedimentos da análise ambiental, daqueles que são gerais à resolução de problemas, também pareceu bastante indiferenciado nesse exame inicial. Acionando o hipertexto (chamado de biblioteca, no programa), Piter navegou por entre os tópicos de "Estratégias para resolução de problemas" e "Fundamentos da amostragem de poluentes atmosféricos". A sua leitura dos tópicos, em geral, foi completa, embora, algumas vezes, ele tenha mostrado impaciência na leitura ou mesmo falta de objetividade, evidenciada pela entrada ao acaso nos tópicos e pela pouca permanência neles. Portanto, uma vez que o funcionamento do programa e as estratégias de solução 
da análise ambiental permaneciam indistintas, nada se pôde observar em relação ao conhecimento inicial que Piter tinha dos efeitos do problema ambiental e de suas causas. Ora, conforme foi tratado na introdução, a análise ambiental inclui a identificação dos efeitos que designam o problema em foco. Além disso, devido a uma representação prévia de algumas relações imbricadas no problema, o sujeito pode atribuir, de forma quase imediata, um nexo causal bastante próximo do que existe de fato. O seguinte extrato permite ilustrar essa etapa da análise ambiental.

No caso Paulo, a reconstrução cognitiva do vínculo causal foi bastante direta. A partir das entrevistas com a relações-públicas da usina e com um minerador de carvão, Paulo diferenciou algumas informações relacionadas ao carvão, copiando-as no bloco de notas: o índice de 6\% para o enxofre e seu impacto poluidor. A identificação do valor do enxofre serviu para a objetivação de sua hipótese, uma vez que não só a fumaça da usina deveria ser a causa da poluição, mas o enxofre também passara a constituir a hipótese causal. Durante a navegação no hipertexto, Paulo consolidou tanto sua hipótese em relação ao enxofre como fator causal, quanto o procedimento de análise das amostras, integrando-os na ação de análise do parâmetro dióxido de enxofre, conforme evidencia a seguinte fala: (Paulo): "Bom, o que eu acho assim, pelo que en fui olhando ali, né, é o alto indice do dióxido, é dióxido, né?, de enxofre no ar, que estava causando problemas com o gado e com as plantaçôs, que tava, também, dando problema para a economia do município, no caso.". Dessa forma, ele obteve um rápido sucesso que lhe seria decisivo para a continuidade dos procedimentos de análise e de navegação pelo hipertexto. Esses foram, então, fortemente dirigidos pela hipótese do dióxido de enxofre como fator causal.

Porém, a passagem das evidências do problema para a formulação de um esboço causal pode ser bem mais gradual e progressiva durante a análise ambiental. Nesse sentido, pode-se estar procurando um maior e melhor relacionamento entre os vários componentes envolvidos no problema. Por exemplo, Piter buscava se informar sobre os diferentes efeitos descritos pelos diversos personagens nas entrevistas. Então, à medida que os efeitos iam sendo diferenciados e localizados geograficamente, uma primeira atribuição causal - ainda longe da indicação do dióxido de enxofre como fator da poluição começava a se articular e os procedimentos ficavam mais distintos. O seguinte extrato pode ilustrar isso: (Entrevistador): "Qual éo problema que está acontece ali? (Piter): Deve ser, eu acho que a poluição do ar é que tá estragando a plantação, né, de soja. (Entrevistador): Por que tu achas que é a poluição do ar? (Piter): Por causa da usina que tem, né, perto da cidade. Tem aqui a usina termoelétrica e a mina de carvão. (Entrevistador): Como é que tu vais poder confirmar se essa tua idéia está certa? (Piter): Fazer uma amostragem no ar, para ver como é que tá o ar."

A análise ambiental também supõe alguma forma de confirmar ou comprovar a hipótese que conduz a investigação em curso, conforme se pode verificar pelo excerto anterior. Nesse sentido, inclusive segundo a legislação específica, a evidência corroborante da atribuição causal é a análise qualitativa e quantitativa de amostras do sistema em estudo. No problema em foco, as amostras seriam coletadas do ar e analisadas para verificar a concentração dos seus diversos constituintes. Nesse caso, conforme a hipótese que dirigiu o exame das amostras de ar, os procedimentos manifestados pelos sujeitos foram bastante diferentes.

Em poucas ações com o programa, Paulo já buscava evidências para confirmar sua hipótese. Durante a consulta no hipertexto, por exemplo, ele copiou informações para o bloco de notas sobre os valores permissíveis para o dióxido de enxofre na atmosfera e sobre os efeitos da poluição do dióxido de enxofre na saúde humana. Assim ele resumiu esse seu procedimento: (Paulo): "Eu vi os indices que tinham de enxofre no carvão deles, depois eu olhei na biblioteca qual os indices que eram prejudiciais. E coincidiu'. Em seguida, para que confirmasse, de maneira cabal, sua hipótese, ele ampliou um pouco o número de amostradores no mapa colocando, inclusive, um amostrador em uma região que ele cria não estar sob os efeitos da poluição, à direita da usina. Uma vez que o seu procedimento de análise já estava bastante consolidado, executou a análise do dióxido de enxofre, confirmando sua hipótese sobre o fator causal do problema ambiental. Então, concluiu estar apto para preencher o relatório que integraria seus conhecimentos sobre a identificação do problema.

O caminho de Piter, mais uma vez, foi bem mais longo. Conforme citado, anteriormente, ele compreendeu a necessidade de amostrar o ar. Naquele momento, ele pareceu sistematizar duas funções do programa que já entendera: as entrevistas e a colocação dos amostradores. Assim, ele retomou as entrevistas, inclusive prestando atenção ao depoimento de moradores que já lera, e instalou uma série de amostradores, distribuindo-os por todas diferentes regiões do mapa, as mesmas as quais as entrevistas estão associadas. Em cada entrevista, ele copiou para o bloco de notas as frases dos depoimentos que mais lhe chamaram a atenção, dando título a essas frases, para que não esquecesse com quem elas se relacionaram. Piter justificou esse seu procedimento da seguinte forma: (Piter): “...para, no final, eu ter uma base, né. Eu fiz a entrevista com todos aquelas pessoas possiveis, depois juntar as idéias, ver os 
fatos e ver o que aconteceu. Tem algumas fazendas que não foram afetadas. (Entrevistador): E essas fazendas que não foram afetadas são aonde? (Piter): Estão, eu acho que, na parte leste". Além disso: (Entrevistador): "Porque tu fizeste essas entrevistas? (Piter): Para saber onde tem os focos de poluição". Pode-se depreender disso que ele já começara a diferenciar os efeitos de uma relação geográfica que, paulatinamente, iria ser refinada e orientaria a disposição dos amostradores sobre o mapa. No entanto, embora Piter reconhecesse o ar como o fator de dispersão dos poluentes, ainda não se reportava a qualquer constituinte do ar como o fator causal dos efeitos observados. Nesse sentido, também não é de se estranhar que ele não diferenciasse os dois procedimentos (a amostragem e a análise) pertinentes à análise ambiental: (Entrevistador): "E como é que tu faz. essa amostragem? (Piter): Tu vai ali, bota um tipo de um icone, naquela parte do ar e vê, né. (Entrevistador): E depois da amostragem, o que tu tem de fazer, tu sabes? (Piter): Dai eu não sei". Além do mais, a solução que propunha ao problema manifestava característica essencialmente figurativa: (Entrevistador): " $E$ se tu confirmares que estás certo, como é que tu achas que pode ser resolvido esse problema? (Piter): Tentar mudar o lugar da mina de carvão, né, e da usina termoelétrica. Falar com o Prefeito e tentar mudar". De certa forma, isso enfatiza a falta de objetividade que, nesse momento, ele manifestava.

Note-se que a atribuição causal, muitas vezes efetivamente passa por um refinamento. Se por um lado, Paulo logo diferenciara corretamente o nexo causal do problema, por outro lado, Piter passou por um caminho que evidencia as descobertas que alcançou. No início da segunda sessão, Piter escolheu vários parâmetros de análise para as amostra do ar, comparando todos os dados obtidos. É importante verificar que Piter procedeu com $\mathrm{a}$ análise de $\mathrm{pH}$ da água da chuva e incluiu esse índice no nexo causal atribuído ao problema, desenvolvendo de forma mais completa seu esboço explicativo: (Piter): "Fazendo as análises do amostrador, eu vi que tem vários outros componentes que também tão a mais e que prejudicam o ar, como o dióxido de enxofre, o monóxido de carbono, óxidos de nitrogênio e ozônio, e também a água da chuva, né, que é uma água ácida. (Entrevistador): Porque a água tá ácida? (Piter): Por causa do, porque tem, tá dando, tem vários componentes no ar, na água também, sabe? Tem outros ácidos que provocam, acidez da chuva, $n \hat{e}$. Embora Piter tenha manifestado um procedimento de análise envolvendo praticamente todos os padrões de análise, isso não evidencia, necessariamente, que ele não tenha construído alguma hipótese acerca da identificação do problema. Ao contrário, ele pareceu desenvolver esse expressivo número de análises para confirmar a relação que ele já esboçara entre o alto índice de dióxido de enxofre e a diminuição no valor do $\mathrm{pH}$. Isso, por

Psicologia: Reflexão e Crítica, 2001, 14(3), pp. 505-520 exemplo, pode ser inferido desde a solução que ele, nesse momento, indicava para resolver o problema: (Entrevistador): " $E$ como é que tu achas que pode resolver o problema? (Piter): Ah, botando alguma coisa no ar, né, que elimine o enxofre". Porém, ele continuava a expressar uma confusão terminológica entre a substância elementar enxofre, presente no carvão queimado na usina, e o dióxido de enxofre, o gás reativo que se encontrava no ar, chamando ambos, simplesmente, de enxofre. Esse nexo causal seria, novamente, refinado, mais adiante.

No programa de computador, assim como na análise ambiental real, as descrições dos problemas manifestados e das causas presumidas estão apoiadas pela elaboração de um relatório que, no software, é muito mais resumido, obviamente. Através do preenchimento do relatório também se podem evidenciar os sistemas compreensivos a que se reportam os sujeitos. Nessa oportunidade, novamente Paulo foi conciso e sucinto. Em sua resposta aos problemas identificados, mencionou os respiratórios (sem citar relação com animais ou com os habitantes da cidade) e econômicos (também, sem exemplificar). Essa descrição breve provavelmente tem relação com o grau de integração entre as informações que ele adotara. A causa do problema foi atribuída ao: "(Paulo; extrato da resposta à questão 4, que solicita a descrição detalhada da causa dos problemas observados): alto nivel de $\mathrm{SO}_{2}$ por $m^{3}$ que tem origem na termoelétrica". A quantificação do valor pareceu também estar bem diferenciada, como se pôde notar pela correta recomendação do procedimento a ser realizado em curto prazo: acionamento do plano de emergência no nível de atenção, conforme constava no tópico do hipertexto "Legislação específica".

No entanto, muito diferente foi a atitude de Piter. A sua descrição dos efeitos observados e das causas atribuídas foi bastante rica e integrada. No entanto, ele pareceu não diferenciar efeitos de causas. Nesse caso, ele registrou idéias semelhantes tanto para os efeitos: "(Piter; no relatório, pergunta 2 , que solicita identificar os problemas, listando os efeitos observados): o problema está na quantidade de enxofre que está sendo colocado no carvão. Isso está ocasionando modificações no ar, na água da chuva... que está prejudicando a respiração e até matando pessoas e animais. A água da chuva está acida e está acabando com a plantação de soja. O vento está levando as nuvens com a chuva ácida, e o ar poluído para o leste e norte da região onde tem a cidade e uma fazenda que cria animais que estão morrendo com problemas na respiração"; quanto para as causas: "(Piter; pergunta 4): com a quantidade de enxofre que tem no carvão $\{6 \%\}$ está liberando substâncias que estão poluindo o ar e a água da chuva e o vento leva o ar e as nuvens para a cidade e fazendas que esta ocasionando todo o problema.". 
Além disso, Piter nada indicou sobre os procedimentos de emergência a serem adotados em curto prazo, conforme solicitado na última pergunta do relatório. Embora sua reconstrução do nexo causal ainda envolvesse um quê de artificialismo - ao achar que o enxofre está sendo colocado no carvão -, seu esboço explicativo conseguiu integrar noções de diferentes sistemas, de diferentes segmentos do conhecimento. Para explicar o problema, ele recorreu às transformações químicas no ar e na chuva, ao deslocamento do vento, à precipitação da chuva e aos processos de respiração. Possivelmente, a demora em diferenciar os observáveis relacionados aos efeitos, possibilitou-lhe integrar mais informações em um esboço explicativo rico que remete a um número maior de noções, conceitos e, inclusive, de ciências.

Finalmente, na análise ambiental, concluída a identificação do problema, faz-se necessário propor uma solução para suprimir os efeitos observados. Nesse sentido, é importante ressaltar que o programa não indicava diretamente a eficiência da solução proposta. A eficiência também era verificada de forma conceitual. Entre os vários equipamentos antipoluentes que os sujeitos poderiam instalar no programa, existe um que diminui substancialmente a presença de dióxido de enxofre no ar e sua eficácia na solução é verificada pelo próprio procedimento de análise dos constituintes atmosféricos.

Nesse momento, mais uma vez, Paulo manifestou uma integração coesa e sucinta entre os efeitos observados e as causas atribuídas. Essa integração, por demais ampla, induziu a construção de uma hipótese de solução que contém incorreções na identificação das substâncias químicas envolvidas: "(Paulo): Ah, acho que, pelo o que eu vi ali, tem que instalar uns, na fábrica, na termoelétrica, assim, né, uns controladores de polvição e procurar outras fontes assim, né. Talvez. um carvão que tenha um nivel menor de dió..., dióxidi, dióxido, dióxido de enxofre". Ora, por que ele disse isso? A hipótese causal sobre os efeitos observados foi relacionada, de início, ao dióxido de enxofre, o qual não seria o termo mais próximo de tais efeitos, como a chuva ácida, por exemplo. Dessa forma, não houve a necessidade de progredir no desenvolvimento do nexo causal pela reatividade química envolvida e de suas compreensões parciais. Nesse sentido, os processos químicos que levam à formação da chuva ácida não fizeram parte do esboço explicativo que Paulo utilizou na solução do problema. Assim, pode ser que a falta de compreensão sobre as transformações químicas por que passam as substâncias, ou a tomada de consciência tardia dessa reatividade, tenham induzido Paulo a crer que realmente existia dióxido de enxofre no carvão. No entanto, uma vez que inicialmente ele tinha destacado a existência do teor de
6\% de enxofre no carvão, conforme consta em seu bloco de notas, pode-se pensar que ele confundia as substâncias enxofre elementar e dióxido de enxofre.

Mais uma vez, o caminho percorrido por Piter foi outro. Ele se dirigiu à proposição de sua solução sem que manifestasse um objetivo muito claro sobre a forma de fazê-lo, ou seja, sem saber que o sistema de controle deveria instalar ou qual hipótese poderia orientar sua procura pelo melhor equipamento. Durante a leitura do tópico relacionado aos sistemas de controle de poluição, manifestou que noções econômicas poderiam dirigir sua busca pelo equipamento mais eficiente: (Entrevistador): "Como assim se tem dinheiro? (Piter): Sim, quanto é que eu vou gastarpra botar esses aparelhos? Não tem nenhum dinheiro minimo para que eu posso botar? (Entrevistador): Ah, não. (Piter): Posso botar todos se eu quiser?". Nesse sentido, em função da afirmativa, o procedimento para a busca pelo equipamento mais eficiente que ele empregou foi baseado na exploração ampla, na sondagem sistemática. Ainda mais, Piter assim justificou a instalação do primeiro equipamento antipoluente, indicando não estar seguindo uma hipótese articulada, como fizera nas análises: (Entrevistador): "Qual é o aparelho que tu querias instalar? Qual é o que tu achas que deveria instalar? (Piter): Ah! Não sei, tem que ver aqui. Gostei de um filtro de ar [de arraste mecânico]". Além disso, essa orientação pelas questões econômicas, ou em outras palavras, a falta de custos e de créditos para executar cada procedimento pretendido, por exemplo, pode ter influenciado o grande número de análises que ele desenvolveu na primeira fase do programa, bem como seu procedimento de análise sistemática dos diversos parâmetros para confirmar a relação presumida entre o aumento da acidez da chuva e o alto índice de dióxido de enxofre.

$\mathrm{Na}$ averiguação da eficiência dos equipamentos antipoluentes, entretanto, ambos sujeitos pareceram seguir a mesma estratégia. Logo no início dessa fase, Paulo não manifestou conhecimento de como deveria proceder, tanto que tentou verificar se os depoimentos dos moradores da região estariam diferentes. Em função dessa negativa, buscou a instalação dos equipamentos, fazendoo sem parecer se orientar por uma hipótese causal bem definida. Ele instalou dois equipamentos, de forma aparentemente aleatória, e procedeu à análise de dióxido de enxofre, verificando a ineficiência desse equipamento. A análise desenvolvida indicou a eficiência do equipamento para dessulfuração de combustíveis fósseis. Ele mesmo reportou sua característica de sondagem: (Paulo): "para mim ir testando qual iria dar, qual iria funcionar melhor, né. Tinham vários tipos, tinham vários funções. Alguns diminuiam um pouquinho, outros nada. Dai eu cheguei a um que, 
que diminuiu bastante. Daí eu li tudo ali, sobre o equipamento, daí en vi que era específico para aquilo que en tava procurando".

Embora Piter também tenha manifestado essa tendência por tentativas na instalação de equipamento antipoluente, é interessante verificar a integração que ele realizou entre dois fatores causais relacionados ao problema simulado. No início de seus procedimentos para a avaliação da eficiência dos diferentes equipamentos antipoluentes instalados, ele buscou a análise da água da chuva, procedimento que se revelara eficiente na primeira fase do programa. Ora, esse é o fator causal mais próximo aos efeitos observados. Posteriormente, ao avançar na instalação de outros equipamentos, ele toma consciência que não é necessário verificar os valores de $\mathrm{pH}$ da água da chuva, pois bastaria analisar o dióxido de enxofre e comparar os seus índices antes e depois da instalação de certo equipamento. Assim, Piter evolui a sua noção sobre a causação do problema. Ou seja, ele integrou o procedimento de análise de água da chuva e análise do dióxido de enxofre em um só, pois no nexo causal ambos estão relacionados. Nesse caso, Piter entendeu que a diminuição do $\mathrm{pH}$ da água da chuva estava sendo causada pelo alto índice de dióxido de enxofre no ar. Em outras palavras, ele desenvolve um pouco mais o nexo causal, refinando a causa atribuída ao problema: (Entrevistador): "Como é que o carvão poluía o ar? (Piter):
Soltava, eu acho. Eu acho que enxofre, né. Soltava o enxofre no ar. (Entrevistador): Como é que ele soltava esse enxofre no ar? (Piter): Na queima. (Entrevistador): E o que soltava no ar? (Piter): $A h, o\{\ldots\}$ [não se conseguiu compreender] de enxofre. (Entrevistador): O que soltava no ar, como é que fazia, como é que ocorria essa chuva ácida? (Piter): Misturava com outras substâncias que tinha no ar. (Entrevistador): Quais substâncias? (Piter): $A$ h, o $\mathrm{SO}_{2}$ [dióxido de enxofre], substâncias que eu tinha que ver, provocava uma reação, uma reação química com a água da chuva”. Na continuação do uso do programa, seguiu usando o procedimento de instalação sistemática dos equipamentos e averiguação da eficiência através da análise do dióxido de enxofre até encontrar o mais eficaz.

Uma situação inesperada foi a atitude matreira de Piter. Em vários momentos das sessões, Piter se mostrou preocupado com o desempenho dos seus colegas que também participavam da pesquisa. Em sua segunda sessão, por exemplo, ele já perguntara sobre o desempenho de Cláudio (15 anos e dois meses, resolveu a tarefa em três sessões) e de Mathias (15 anos e quatro meses, resolveu a tarefa em quatro sessões). Em outro dia, no qual o experimento estava sendo realizado com Paulo, ele veio fazer algumas perguntas e indicar certezas que poderia desenvolver na próxima sessão. Finalmente, no final de sua terceira sessão, Piter disse estranhar o interesse de Lia (17 anos, participou de uma sessão e não

Tabela 1. Excerto do Arquivo de Histórico de Piter

\begin{tabular}{lc}
\hline Ação & Hora \\
\hline Inicio & $04 / 10 / 9914: 30: 23$ \\
Relatório Análise Poluentes & $04 / 10 / 9914: 30: 28$ \\
Solucionou Problema & $04 / 10 / 9914: 31: 34$ \\
Inicio & $04 / 10 / 9914: 31: 59$ \\
Tópico da Biblioteca 100 & $04 / 10 / 9914: 32: 39$ \\
Analisou SO2 & $04 / 10 / 9914: 32: 40$ \\
Relatório Análise Poluentes & $04 / 10 / 9914: 32: 59$ \\
Solucionou Problema & $04 / 10 / 9914: 35: 51$ \\
Inicio & $04 / 10 / 9914: 37: 44$ \\
Tópico da Biblioteca 460 & $04 / 10 / 9914: 38: 35$ \\
Colocou Precipitador Eletrostático & $04 / 10 / 9914: 38: 42$ \\
Tópico da Biblioteca 100 & $04 / 10 / 9914: 39: 04$ \\
Analisou SO2 & $04 / 10 / 9914: 39: 06$ \\
Tópico da Biblioteca 270 & $04 / 10 / 9914: 39: 42$ \\
Colocou Dessulfurizador & $04 / 10 / 9914: 39: 44$ \\
Tópico da Biblioteca 100 & $04 / 10 / 9914: 39: 55$ \\
Analisou SO2 & $04 / 10 / 9914: 39: 56$ \\
Relatório Análise Poluentes & $04 / 10 / 9914: 41: 33$ \\
Relatório Análise Poluentes & $04 / 10 / 9914: 44: 11$ \\
Relatório Análise Poluentes & $04 / 10 / 9914: 44: 41$ \\
Solucionou Problema & $04 / 10 / 9914: 45: 02$ \\
\hline
\end{tabular}


resolveu a tarefa) pela atividade, uma vez que isso "não era muito do estilo dela". Talvez o conjunto dessas ansiedades e da preocupação pelo desempenho dos outros possa ter levado Piter a utilizar o programa sem a assistência do entrevistador, conforme havia sido combinado. Dessa forma, em um dos dias não foi possível fazer as observações e as gravações em áudio como vinha ocorrendo até então. $\mathrm{O}$ único dado sobre a navegação desse dia consiste nos arquivos de histórico, conforme Tabela 1. Nessa pequena navegação, Piter concluiu seu procedimento de averiguação dos equipamentos antipoluentes instalados. Disso depreende-se que os arquivos de histórico podem ser úteis para a interpretação de padrões de navegação, embora isolados, certamente, não permitam o mesmo tipo de inferência.

Finalmente, uma vez que a atividade proposta na tarefa era uma simulação, quis-se verificar a relação que os sujeitos faziam entre a situação simbólica e os casos reais. Nesse sentido, Piter manifestou uma resposta exemplar, integrando noções econômicas: (Entrevistador): " $E$ tu achas que da maneira que tu resolveste o problema no computador, seria a maneira de tu resolveres ele na realidade? (Piter): Acho que sim, né. É que, no computador, não mostra assim, mais ou menos, os gastos, os lucros, né. Mostra, mas não diz se vai dar prejuízo ou não. Se não derprejuízo, acho que é obrigado, né. (Entrevistador): Eu tava vendo que tanto agora na tua resposta, né, quanto na maneira como tu usavas, tu sempre recorreste a essa questão econômica. Porque tu achas que isso é relevante dentro desse problema? (Piter): É. Se desse prejuizo para eles botar aquilo, com certeza, não ia ter. Então, tinha que arranjar outra forma. Ou eles iam continuar poluindo o ar, ou iam fechar a usina. Ou eles fechavam, ou pegavam um troço que dava lucro para eles. (Entrevistador): E se fosse prejuízo para o pessoal da usina, para não pôr o equipamento, como é que ficaria o pessoal da cidade? (Piter): Eu acho que ia ficar, por um lado bom, né, ia ter energia, tudo, mas a população ia respirar mal. Ia cada vez morrendo mais".

Por outro lado, ele não fez uso das noções jurídicas que faziam parte da solução do problema proposto. No preenchimento de ambos os relatórios, a questão sobre as medidas emergenciais, conforme prescrito na legislação específica, foi deixada de lado.

\section{Discussão}

No decorrer desta pesquisa, continuamente se observou dois comportamentos distintos. Em um deles, pode-se dizer, o sujeito constrói uma hipótese acerca do problema e, a partir dessa hipótese, utiliza estratégias e procedimentos frente ao problema em questão. No outro, o sujeito interpreta as características apresentadas pelo meio sobre o qual ele tenta resolver o problema e constrói novos sistemas de procedimentos. Diversos estudos também têm evidenciado em diferentes domínios do conhecimento, esses dois tipos de controle do sistema cognitivo, que podem ser denominados, respectivamente: descendente e ascendente (Mosca, Silveira \& Burigo, 1993); top-down e botton-up (Beasley \& Waugh, 1997; Jacques \& Fagundes, 1999); inferências para frente (da predição à conseqüência) e inferências para trás (das conseqüências à predição) (Bindra, Clarke \& Shultz, 1980); ou baseados nas idéias e baseados na evidência (Park \& Pak, 1997).

Nesta seção, discute-se algumas das condutas cognitivas envolvidas na solução de problemas ambientais. Em geral, a apresentação dessas condutas está acompanhada de uma teorização sobre as estratégias voltadas às descobertas, proposta por Inhelder e Caprona (1992/1996a, 1992/1996b).

Em relação à tarefa proposta, normalmente, conforme foram sendo diferenciados os significados que constituem a novidade do problema a ser solucionado, o sujeito fez para si uma “(...) primeira representação do estado final desejado, e suas ações [fixaram] mais o objetivo a ser atingido do que o meio de resolução." (Inhelder \& Caprona, 1992/1996b, p. 43). Além disso, essa representação inicial do sujeito envolveu a ativação de conhecimentos representativos e procedimentais, anteriormente adquiridos (Mosca, Silveira \& Burigo, 1993). Nesse caso, suas atitudes estiveram relacionadas às idéias prévias que os sujeitos tinham sobre as relações causais entre os fatores em questão na tarefa (Park \& Pak, 1997).

Além da representação do estado final, também foram sendo diferenciadas progressivamente as características do método analítico. Os procedimentos de análise das amostras de ar ou água da chuva foram, em geral, a forma de confirmação das hipóteses dos sujeitos. De outra forma, na análise ambiental, enquanto não se reconhece essa sucessão, não avança o processo de inspeção de hipóteses.

Nesse caso, os procedimentos que iam sendo inventados pelo sujeito dependiam, também, do descobrimento de como executar tais procedimentos com o programa de computador. Dessa forma, não é só o conhecimento dos conceitos que se relacionam ao conhecimento dos procedimentos, há também a questão do conhecimento do aparelho, do aparato, da tecnologia. Assim, pode-se dizer que essa tríade de conhecimentos teve um caminho de diferenciação mutuamente relacionado, de forma que o desenvolvimento de um componente, possibilitou o progresso do outro. Também, de outra forma, uma diferenciação muito tardia em um dos componentes dessa tríade dificultou sobremaneira a solução do problema proposto pelo software. Assim, o 
sujeito planejava suas ações à medida que diferenciava os conceitos relacionados aos efeitos e às causas do problema proposto, os procedimentos para a solução do problema (resumidamente: amostragem e análise, identificação do problema e instalação de equipamento antipoluente eficiente) e as ferramentas e as funções presentes na simulação do computador.

No entanto, esses novos observáveis não foram escolhidos aleatoriamente. Eles o foram por se integrar a uma representação que se apóia sem outras anteriores. Isso porque, “(...) os sujeitos procuram inicialmente explicar os fenômenos através de uma teoria geral implícita, à qual se atêm a ponto de generalizá-la." (Inhelder \& Caprona, 1992/1996b, p. 47). Então, uma vez que surjam fatos ou informações que sejam imprevistos aos sujeitos, eles podem criar outras representações, diferentes daquelas com as quais vinham trabalhando. Dessa forma, o sucesso ou o fracasso na ação pode levar os sujeitos a reestruturar conceitualmente o problema que estão operando. Porém, “(...) um fenômeno freqüentemente observado é a inadequação do esquema posto a funcionar inicialmente, e que se constitui em obstáculo para a resolução do problema." (Inhelder \& Caprona, 1992/1996b, p. 72). Nesse caso, a reorientação das condutas em curso passou pela tomada de consciência de tal impedimento.

Em relação às reorientações dos procedimentos, uma interessante particularidade encontrada foi a tomada de consciência da necessidade de aprimorar os procedimentos pela atenção à leitura dos tópicos constantes da biblioteca. Nesse sentido, também a seleção do que os sujeitos julgam necessário ler é reveladora. Alguns sujeitos manifestaram pouco conhecimento sobre o caminho que deveriam tomar para resolver o problema e, nessa ocasião, procuraram reler o tópico relacionado às "Estratégias para a resolução de problemas", o que lhes proporcionou um apoio para a continuidade de suas ações. Essa tomada de consciência é mais uma evidência que corrobora uma tese que tem sido defendida por um grupo de professores de português (Guedes \& Souza, 1998): a leitura e a escrita são tarefas dos professores de todas as disciplinas.

Assim, as hipóteses iniciais sobre o nexo causal do problema e sobre os procedimentos a serem desenvolvidos para sua solução, progressivamente foram sendo refinadas, depuradas e postas à prova. Nesse momento, seus êxitos e seus fracassos lhes serviram de sinalizador na seqüência dos percursos, pois o êxito prático permitiu aos sujeitos estabelecer recorrências que aparecem quando a repetição das mesmas ações produz os mesmos resultados positivos. O fracasso, por seu lado,

Psicologia: Reflexão e Crítica, 2001, 14(3), pp. 505-520 provocou uma busca relativa ao procedimento ou às propriedades do objeto. Por isso, entende-se que “(...) os fracassos, ao provocarem fases de exploração, desembocam em novos focos de observação, sendo, portanto, também condições de progresso, uma vez que suscitam uma busca daquilo que causa o insucesso." (Inhelder \& Caprona, 1992/1996b, p. 49).

Os procedimentos que evidenciaram o êxito, o fracasso, a hipótese e suas reorientações foram, entre outros: a disposição geográfica dos amostradores junto ao mapa temático que representa a região de Carbópolis e a escolha dos parâmetros a serem executados para a análise das amostras coletadas. Ora, esse tipo de apoio espacial, ainda que no problema desta pesquisa tenham também implicações simbólicas, faz parte da resolução de um problema, uma vez que “(...) o sujeito deve dispor (...) de um quadro de referências para situar os elementos necessários à solução de um problema." (Inhelder \& Caprona, 1992/1996b, pp. 64-65).

Nesse sentido, as representações espaciais têm dois papéis. Em primeiro lugar, o sujeito deve formar uma visão do conjunto das conexões possíveis entre as informações, subjacentes ao mapa temático, acessíveis pelo uso do mouse. Desse modo, convém notar que no momento em que o sujeito busca a solução do problema, escolhendo um certo ponto de referência sobre esse mapa, seu universo se restringe e se centra. $O$ exxito na tarefa supõe que o sujeito domine as diferentes formas de representação, espaciais e temporais (porém, em nosso caso, ambas simbólicas), para que possa identificar o problema: relaciona as medições dos poluentes com a indicação da localização dos amostradores (na Figura 1, estão numerados de 1 a 5), os ícones e os comandos disponíveis, entendendo suas funções e as situando corretamente. Dessa maneira, foram evidenciadas relações entre a compreensão de símbolos contidos em mapas e a alocação, distribuição e orientação de efeitos ligados a problemas ambientais, conforme tem sido defendido por alguns especialistas em ensino e aprendizagem de geografia (Gregg, 1997).

Em relação aos conceitos ou, nesse particular, ao entendimento das causas do problema ambiental, a tomada de consciência em direção à objetividade é gradual, mas oferece resistências, por certo. A escolha dos parâmetros de análise e a justificativa para tal escolha também puderam evidenciar a hipótese causal que o sujeito atribuiu ao problema. Além disso, o parâmetro escolhido para a análise (material particulado, hidrocarbonetos, monóxido de carbono, oxidantes fotoquímicos, dióxido de enxofre ou $\mathrm{pH}$ da água da chuva) pôde, também, indicar os dois controles cognitivos 
utilizados pelos sujeitos: se dirigidos por uma hipótese ou se pela elaboração de fatos contingentes.

No entanto, apesar de todos os sucessos, graduais ou imediatos, a justificativa sobre a utilização do procedimento, bem como a explicação causal dada ao problema em solução, manifestaram inconsistências. Um dos motivos evidenciados esteve, provavelmente, relacionado a incorreções de linguagem e de nomeação. Tais aspectos semióticos podem, dessa forma, ser colocados em relação à formação dos símbolos, pois a noção de representação comporta dois aspectos complementares e indissociáveis, o sentido e a referência, que possibilitam ao sujeito refletir sobre os fins e os meios que ele se propõe. Então, “(...) esses dois aspectos definem a função essencialmente instrumental da representação (...): concorrem para a formação de instrumentos cognitivos que se tornam, para o sujeito, 'objetos que ajudam a pensar'.” (Inhelder \& Caprona, 1992/1996a, p. 34; grifo dos autores).

Então, se a linguagem é também uma representação que cumpre uma função de auxílio ao pensar, não é estranho que, no seio da química, por exemplo, essa seja uma noção que reporta ao atribuído fundador da química moderna:

"Lavoisier manifesta um firme interesse pela nomenclatura e pelas questões da linguagem. Antes dele, a química e a linguagem não formavam um par harmonioso: era lugar-comum, para os filósofos, deplorar o modo como se exprimiam os químicos. (...) Quando Lavoisier revolucionou a química, em 1789, o seu Discurso Preliminaré um hino à importância de uma denominação precisa e minuciosa (...): ‘como são as palavras que conservam as idéias e as transmitem, sucede que não pode aperfeiçoar-se a linguagem sem aperfeiçoar a ciência, nem a ciência sem a linguagem, e que, quaisquer que fossem os fatos, por mais justas que fossem as idéias que os fizeram nascer, eles apenas transmitem impressões falsas se não tivéssemos expressões exatas para os traduzir.'” (Laszlo, 1995, p.42; grifos do autor) Um outro exemplo das dificuldades de entendimento da química relacionadas à linguagem apareceu na etapa de solução do problema. O único equipamento eficiente para suprimir a causa da poluição se chama dessulfurizador, isso porque ele procede a dessulfuração dos combustíveis fósseis, ou seja, retira o enxofre presente nesses combustíveis. Porém, qual a relação entre o termo enxofre e o afixo sulfur? Isso pode parecer óbvio para um químico, mas não é de domínio geral. Nesse sentido, essa ausência de associação de termos pôde indicar a relativa dificuldade de certos sujeitos em estabelecer o método de controle de poluição do ar mais eficiente para o problema proposto, mesmo que a essa dificuldade se deva acrescentar a falta de atenção na leitura dos tópicos relacionados aos equipamentos.
Finalmente, cabem algumas palavras relacionadas à integração interdisciplinar que a análise ambiental enseja (Tauk-Tornisielo, Gobbi \& Fowler, 1995). Nesta pesquisa, nenhum dos oito sujeitos participantes chegou a manifestar a integração de todos os diferentes sistemas relacionados aos temas ambientais. Ora, nem poderia ser diferente: Fowler e Aguiar (1995) já advertiram o quanto isso é difícil de ser verificado no próprio exercício profissional. Mesmo assim, a maioria dos sistemas foi representada pelo uso, ainda que esporádico, das diversas noções, por diferentes sujeitos. No entanto, a reconstrução cognitiva da solução do problema ambiental manifestou pouca articulação com as noções jurídicas imbricadas. Nesse sentido, é interessante verificar que Piaget (1972) já citara as dificuldades possíveis à emergência do pensamento jurídico.

$\mathrm{Na}$ introdução deste artigo, nós estabelecemos alguns pressupostos que foram úteis ao desenvolvimento desta pesquisa. Por exemplo, no princípio, entendemos que, com certos problemas ambientais que têm um nítido domínio causal, seria possível realizar um estudo para verificar as condutas cognitivas manifestadas, as estratégias que os sujeitos desenvolvem em suas análises e os sistemas compreensivos a que se reportam. A realização de pesquisas com esse objetivo poderia, também, seguir os métodos qualitativos de inspiração piagetiana propostos por Inhelder e Caprona (1992/1996a, 1992/1996b), para o qual seriam necessárias algumas adaptações, caso sejam usadas simulações educacionais, conforme compreendemos ser possível.

As conclusões a que chegamos parecem fortalecer essas idéias, uma vez que os casos prototípicos, por nós analisados, foram oportunidades de evidenciar as estratégias de resolução de problemas ambientais. Portanto, entendemos que, talvez, com uma maior quantidade de investigações se possa generalizar sobre as estratégias de resolução de problemas nesse campo conceitual. Nesse sentido, alguns dos próximos estudos de um dos autores deste artigo envolverão a reconstrução do nexo causal de problemas ambientais e sociais relacionados aos diferentes meios de produção de energia elétrica (Eichler \& Del Pino, 1998).

\section{Referências}

Barab, S. A., Bawdish, B. R. \& Lawless, K. A. (1997). Hypermedia navigation: profiles of hypermedia users. Educational Technology Research and Development, 45(3), 23-41.

Beasley, R.E. \& Waugh, M.L. (1997). Predominant initial and review patterns of navigation in a fully constrained hypermedia hierarchy: An empirical study. Journal of Educational Multimedia and Hypermedia, 6(2), 155-172. 
Bindra, D.; Clarke, K.A. \& Shultz, T.R. (1980). Understanding predictive relations of necessity and sufficiency in formally equivalent "causal" and "logical" problems. Journal of Experimental Psychology: General, 109(4), $422-443$.

Blanchet, A. (1996). Unidades de procedimentos, causais e telenômicas, no estudo dos processos cognitivos. Em B. Inhelder \& G. Cellérier (Orgs.), O desenrolar das descobertas da criança: um estudo sobre as microgêneses. cognitivas (E. Gruman, Trad.; pp. 80-106). Porto Alegre: Artes Médicas. (Trabalho original publicado em 1992).

Branco, A. \& Rocha, R.F. (1998). A questão da metodologia na investigação científica do desenvolvimento humano. Psicologia: Teoria e Pesquisa, 14(3), 251-258

Bunge, M. (1997). La causalidad: el principio de causalidad en la ciencia moderna $(\mathrm{H}$. Rodriguez, Trad.). Buenos Aires: Sudamericana. (Trabalho original publicado em 1959).

Delval, J. (1996). La fecundidad de la epistemología de Piaget. Substratum, 3(8-9), 89-125.

Dias, G.F. (1992). Educação ambiental: princípios e práticas. São Paulo: Editora Gaia.

Eichler, M. \& Del Pino, J.C. (1998). Modelagem e implementação de ambientes virtuais de aprendizagem em ciências. Em Rede Iberoamericana de Informática na Educação (Org.), Actas, IV Congresso Iberoamericano de Informática na Educaşão [CD-ROM]. Brasília: RIBIE.

Eichler, M. \& Del Pino, J.C. (2000). Carbópolis: um software para educação química. Química Nova na Escola, 11, 10-12.

Eichler, M.; Del Pino, J.C.; Pesa Filho, F.L. \& Vianna, V. (1998). Carbópolis (Versão 1.1) [Software]. Porto Alegre: Área de Educação Química. (http://www.iq.ufrgs.br/aeq/ carbop.htm).

Eivazian, A.M.B. (1995). O ensino de ciência usando simulações. Acesso, (Dezembro), 17-20.

Ferreiro, E. (1996). Aplicar, replicar, recriar. Acerca de las dificultades inherentes a la incorporación de nuevos objetos al cuerpo teórico de la teoría de Piaget. Substratum, 3 (8-9), 175-185.

Fiedler, H.; Martins, A.F. \& Solari, J.A. (1990). Meio ambiente e complexos carboeléticos: o caso Candiota. Ciência Hoje, 12 (68), 38-45.

Fiedler, H. \& Solari, J.A. (1991). Concentração de metais em aerossóis atmosféricos. Ambiente, 5 (1), 26-32.

Fowler, H.G. \& Aguiar, A.M.D. (1995). A integração da teoria ecológica na análise ambiental. Em S.M. Tauk-Tornisielo, N. Gobbi \& H.G. Fowler (Orgs.), Análise ambiental: uma visão multidisciplinar (pp. 166-175). São Paulo: Editora da Universidade Estadual Paulista.

Freitag, B. (1997). Piaget: 100 anos. São Paulo: Cortez.

Garcia, R. (1996). Crear e comprender. La concepción piagetiana del conocimiento. Substratum, 3 (8-9), 53-62.

Giacoia Jr., O. (1996). Hans Jonas: o princípio da responsabilidade. Cadernos de História e Filosofia da Ciência, 6 (2), 63-84.

Gregg, M. (1997). Problem posing from maps: utilizing understanding. Journal of Geography, 96 (5), 250-256.

Grize, J.B. (1997). Psicologia genética e lógica. Em L. Banks-Leite (Org.), Percursos piagetianos (pp. 63-76). São Paulo: Cortez.

Guedes, P.C. \& Souza, J.M. (1998). Leitura e escrita são tarefas da escola e não só do professor de português. Em P.C. Guedes \& J.V. Souza (Orgs.), Ler e escrever: compromisso de todas as áreas (pp. 13-18). Porto Alegre: Ed. da Universidade/UFRGS.

Hilton, D. J. (1990). Conversational processes and causal explanation. Psychological Bulletin, 107(1), 65-81.

Inhelder, B. \& Caprona, D. (1996a). Rumo ao construtivismo psicológico: estruturas? Procedimentos? Os dois “indissociáveis". Em B. Inhelder \& G. Cellérier (Orgs.), O desenrolar das descobertas da crianca: um estudo sobre as microgêneses cognitivas (E. Gruman, Trad.; pp. 7-37). Porto Alegre: Artes Médicas. (Trabalho original publicado em 1992)

Inhelder, B. \& Caprona, D. (1996b). Um percurso de pesquisa. Em B. Inhelder \& G. Cellérier (Orgs.), O desenrolar das descobertas da criança: Um estudo sobre as microgêneses cognitivas (E. Gruman, Trad.) (pp. 38-79). Porto Alegre: Artes Médicas. (Trabalho original publicado em 1992)
Inhelder, B. \& Cellérier, G. (1996). O desenrolar das descobertas da crianca: um estudo sobre as microgêneses cognitivas (E. Gruman, Trad.). Porto Alegre: Artes Médicas. (Trabalho original publicado em 1992)

Jacques, T. G. \& Fagundes, L. C. (1999). Procedimentos: O desenrolar das ações/operações na construção de apresentações hipermídia. Informática na Educacão: Teoria \& Prática, 2(2), 99-108.

Lawson, A.E. (1983). The effects of causality, response alternatives and context continuity on hypothesis testing reasoning. Journal of Experimental Education, 46(1), 41-46.

Laszlo, P. (1995). A palavra das coisas: ou a linguagem da Química (R. Gonçalves \& A. Simões, Trads.). Lisboa: Gradiva.

Macedo, R.K. (1995). A importância da avaliação ambiental. Em S. M. Tauk-Tornisielo, N. Gobbi \& H. G. Fowler (Orgs.), Análise ambiental: Uma visão multidisciplinar (pp. 13-31). São Paulo: Editora da Universidade Estadual Paulista.

Meira, L. (1994). Análise microgenética e videografia: Ferramentas de pesquisa em psicologia cognitiva. Temas em Psicologia, 3, 59-71.

Moro, M.L.F. (2000). A epistemologia genética e a interação social de crianças. Psicologia: Reflexão e Crítica, 13(2), 295-310.

Mosca, P. R. F., Silveira, J. F. P \& Burigo, E. (1993). Processos cognitivos na resolução de problemas no campo da matemática: o caso da interação com programas-semente. Psicologia: Reflexão e Crítica, 6(1/2), 57-83.

Newton, D. P. (1996). Causal situations in science: a modal for supporting understanding. Learning and Instruction, 6(3), 201-217.

Park, J. \& Pak, S. (1997). Student's responses to experimental evidence based on perceptions of causality and availability of evidence. Journal of Research in Science Teaching, 34(1), 57-67.

Piaget, J. (1972). Intellectual evolution from adolescent to adulthood. Human Development, 15, 1-12.

Piaget, J. (1977). A tomada de consciência (E.B. Souza, Trad.). São Paulo: Melhoramentos, EDUSP. (Trabalho original publicado em 1974)

Piaget, J. (1978). Fazer e compreender (C.L.P. Leite, Trad.). São Paulo: Melhoramentos, EDUSP. (Trabalho original publicado em 1974)

Ramozzi-Chiarottino, Z. (1997). Organismo, lógica e sociedade no modelo piagetiano do conhecimento. Em B. Freitag (Org.), Piaget: 100 anos (pp. 111-122). São Paulo: Cortez.

Rohde, G. M. (1996). Epistemologia ambiental: Uma abordagem filosófica-cientifica sobre a efetuação bumana alopoiética. Porto Alegre: EDIPUCRS.

Saada-Robert, M. (1996a). A construção microgenética de um esquema elementar. Em B. Inhelder \& G. Cellérier (Orgs.), O desenrolar das descobertas da criança: um estudo sobre as microgêneses cognitivas (E. Gruman, Trad.; pp. 107-126). Porto Alegre: Artes Médicas. (Trabalho original publicado em 1992).

Saada-Robert, M. (1996b). Didier e as bonecas russas: Estudo de caso e conceituação. Em B. Inhelder \& G. Cellérier (Orgs.), O desenrolar das descobertas da criança: Um estudo sobre as microgêneses cognitivas (E. Gruman, Trad.; pp. 127-168). Porto Alegre: Artes Médicas. (Trabalho original publicado em 1992)

Siegler, R. S. \& Crowley, K. (1991). The microgenetic method: A direct means for studying cognitive development. American Psychologist, 46(6), 606-620.

Stake, R. E. (1994). Case Study. Em N. Denzin \& Y. Lincoln (Org.), Handbook of Qualitative Research (pp 235-247). Londres: Sage.

Tauk-Tornisielo, S. M., Gobbi, N. \& Fowler, H. G. (1995). Análise ambiental: Uma visão multidisciplinar. São Paulo: Editora da Universidade Estadual Paulista.

White, P. A. (1997). Naïve ecology: Causal judgments about a simple ecosystem. British Journal of Psychology, 88, 219-233. 
Sobre os autores

Marcelo Eichler é Licenciado em Química , pesquisador na Área de Educação Química - UFRGS, doutorando em psicologia pela mesma universidade e bolsista CAPES.

Léa da Cruz Fagundes é Psicóloga e Professora do Programa de Pós-Graduação em Psicologia do

Desenvolvimento e da Personalidade, do Instituto de Psicologia, da Universidade Federal do Rio

Grande do Sul. Coordena o Laboratório de Estudos Cognitivos, nessa mesma universidade. 